\title{
Caracterización de variedades de pasto banderita [Bouteloua curtipendula (Michx.) Torr.] recomendadas para rehabilitación de pastizales
}

\author{
Characterization of varieties of sideoats grama grass \\ [Bouteloua curtipendula (Michx.) Torr.] recommended \\ for rangeland restoration
}

\author{
Raúl Corrales Lermaa, Carlos Raúl Morales Nietoa, Alicia Melgoza Castilloa, J. Santos \\ Sierra Tristánb, Juan Ángel Ortega Gutiérreza, Gerardo Méndez Zamoraa
}

\begin{abstract}
RESUMEN
Con el fin de identificar la mejor variedad de banderita (Bouteloua curtipendula) con el mayor potencial de establecimiento y productividad, se evaluaron cinco variedades comerciales usadas en rehabilitación de pastizales: Niner (Ni), Vaughn (Va), El Reno (Re), Kansas-6107 (K-07) y Kansas-6113 (K-13). Se realizaron dos pruebas bajo condiciones de invernadero con una duración de 77 días. Las variables evaluadas en la prueba uno fueron: emergencia (\% EM), densidad de plantas, altura de planta, materia seca del primer corte, altura de rebrote, materia seca de rebrote y supervivencia ( $\%$ SV). Las variables evaluadas en la prueba dos fueron: longitud de raíz, altura de biomasa aérea y proporción radícula-biomasa aérea. Los datos se analizaron mediante componentes principales, conglomerados y un MANOVA en SAS. Las gráficas de dispersión y dendograma se obtuvieron con MINITAB. Los dos primeros componentes explicaron el $77 \%$ de la variación. Se presentaron diferencias $(P<0.05)$ en la mayoría de las variables, solo \% EM y \% SV no tuvieron significancia. EI CP 2 presentó correlación $(r=85.1 \% ; P<0.0001)$ con $\%$ SV. El análisis de conglomerados integró tres grupos (G): G-1 ( Ni y Va) G-II (Re) y G-III (K-07 y K-13). De acuerdo al análisis multivariado, se clasificaron las variedades por importancia productiva: Ni y Va no presentaron diferencia, pero éstas fueron superiores $(P<0.05)$ al resto de las variedades. Las variedades Vaughn y Niner presentaron el más alto potencial forrajero, El Reno presentó un comportamiento intermedio, y las variedades Kansas-6107 y Kansas-6113 fueron las de menor productividad.
\end{abstract}

PALABRAS ClAVE: Pastos, Clima árido, Productividad, Variación, Rehabilitación.

\begin{abstract}
In order to find the best sideoats grama variety (Bouteloua curtipendula) for rehabilitation, five commercial varieties were evaluated: Niner (Ni), Vaughn (Va), EI Reno (Re), Kansas-6107 (K-07) and Kansas-6113 (K-13). Two tests were carried under a greenhouse during $77 \mathrm{~d}$. In the first test the variables measured were seedling emergence (\% EM), plant density, plant height, dry matter at first cut, height of regrowth, regrowth dry matter and survival (\% SV). In the second test, the variables evaluated were root length, aerial biomass and the ratio of root-aerial biomass. Data analyses were carried out by principal components and cluster analysis by using the Ward method and orthogonal contrasts with MANOVA under SAS. The scatter plots and dendogram were obtained with MINITAB. The first two components explained $77 \%$ of the variation. Differences $(P<0.05)$ occurred in most of the variables, only \% EM and $\%$ SV had no significance. The CP 2 presented correlation $(r=85.1 \%$. $P<0.0001)$ with $\%$ SV. Cluster analysis integrated three groups (G): G-1 (Ni and Va), G-II (Re) and G-III (K-07 and K-13). According to the multivariate analysis, the varieties were classified by productive importance: Va and Ni showed no difference, however, they were higher $(P<0.05)$ than the other varieties. The cultivars Va and $\mathrm{Ni}$ had the highest potential for forage production, Re showed an intermediate performance and the Kansas varieties were the least productive.
\end{abstract}

KEY WORDS: Arid grassland, Grass, Evaluation, Productivity, Variation, Rehabilitation.

Recibido el 11 de julio de 2014. Aceptado el 15 de octubre de 2014.

a Facultad de Zootecnia y Ecología, Universidad Autónoma de Chihuahua. Periférico Francisco R. Almada km 1. 31453 Chihuahua, Chihuahua. México. Tel. (614) 132-0298. cnieto@uach.mx. Correspondencia al segundo autor.

b Sitio Experimental La Campana, Instituto Nacional de Investigaciones Forestales, Agrícolas y Pecuarias (INIFAP). México. 
El sobrepastoreo y pérdida de especies forrajeras nativas es un problema actual en las tierras de pastoreo. En el estado de Chihuahua el $40 \%$ de los 4.6 millones de hectáreas de pastizales medianos abiertos, se encuentran en extremo deterioro $(1,2)$. Por lo anterior, es necesario establecer planes de manejo que incluyan prácticas de rehabilitación de pastizales, utilizando especies nativas mejoradas. Entre estas especies se encuentra el pasto banderita [Bouteloua curtipendula (Michx.) Torr.], nativa de las zonas áridas y semiáridas del norte de México. Las plantas de esta gramínea producen abundante forraje con gran aceptación por el ganado. Se adapta a diferentes tipos de suelo y condiciones climáticas, además, las plantas de esta especie persisten cuando se presenta baja precipitación $(3,4)$. Normalmente se localiza en planicies y lomeríos rocosos, produce alrededor de $1,900 \mathrm{~kg}$ MS ha-1 con precipitaciones de alrededor de $350 \mathrm{~mm}$. Mantiene valores de digestibilidad del 50 al $70 \%$, dependiendo del estado fenológico(5).

La etapa crítica para el establecimiento de pastos es la emergencia de plántulas, lo cual es importante para el éxito de una resiembra. Sin embargo, la selección de la especie y la variedad adecuada para las condiciones del sitio es una decisión fundamental, ya que dentro de la misma especie existen variaciones productivas de comportamiento de acuerdo a la región. Por lo anterior, es importante considerar el comportamiento de la especie y las variedades que se han desarrollado, y que pueden demostrar características deseables en los diferentes sitios agroecológicos donde se utilicen $(6,7)$. Además, la calidad de la semilla es otro factor determinante para la germinación, emergencia y establecimiento, que coadyuvan a que la semilla cumpla con los estándares de calidad de la especie en cuestión(8,9). En otro estudio de producción de semilla, se evaluaron 13 genotipos de pasto banderita y reportan que los mayores rendimientos en cariópside fueron de 6.64 y $8.6 \mathrm{~kg} \mathrm{ha}^{-1}$ para los ecotipos 125 y 303, originarios de Durango y Zacatecas, respectivamente(10). Por la importancia de esta
Overgrazing and loss of native forage species is an ongoing problem in the rangelands. In the state of Chihuahua, $40 \%$ of the 4.6 million hectares of open grasslands are extremely deteriorated $(1,2)$. Therefore, it is necessary to establish management plans that include rangeland restoration practices, using improved native species. Among these species is sideoats grama grass [Bouteloua curtipendula (Michx.) Torr.], native from the arid and semi-arid areas of Northern Mexico. These grass plants produce abundant forage widely accepted by livestock. It adapts to different types of soil and climatic conditions, in addition, plants of this species persist when low rainfall occurs $(3,4)$. Usually located in plains and rocky hillocks, it produces about $1,900 \mathrm{~kg} \mathrm{DM} \mathrm{ha-1}$ with rainfall of about $350 \mathrm{~mm}$. They have digestibility values of 50 to $70 \%$ depending on their growth stage(5).

The critical step for the establishment of pastures is the emergence of seedlings, which is important to the success of replanting. However, the selection of the species and variety suitable for the site conditions is a fundamental decision, because within the same species there are productive changes in behavior according to the region. Therefore, it is important to consider the behavior of the species and varieties that have been developed, and can demonstrate desirable characteristics in different agro-ecological sites that use $(6,7)$. In addition, seed quality is another determinant for germination, emergence and establishment, which contribute to whether the seed meets the quality standards of the species in question $(8,9)$. In another study of seed production, 13 sideoats grama grass genotypes were evaluated and reported that best caryopsis yields were 6.64 and $8.6 \mathrm{~kg} \mathrm{ha}^{-1}$ for the 125 and 303 ecotypes originating in Durango and Zacatecas, respectively $(10)$. Given the importance of this species, it is necessary to characterize and identify sideoats grama grass varieties with potential for establishment in grassland restoration programs. The aim of this study was to characterize the productive behavior of five varieties recommended for reseeding of sideoats grama grass. 
especie, es necesario caracterizar e identificar las variedades de pasto banderita con potencial para su establecimiento en programas de rehabilitación de pastizales. El objetivo de este estudio fue caracterizar el comportamiento productivo de cinco variedades de pasto banderita recomendadas para resiembras.

El estudio se realizó en un invernadero ubicado en la Facultad de Zootecnia y Ecología de la Universidad Autónoma de Chihuahua durante la época de verano en el año 2013. Se utilizaron cinco variedades comerciales de pasto banderita: Niner (Ni), Vaughn (Va), El Reno (Re), Kansas nativa-6107 (K-07) y Kansas nativa-6113 (K13). El experimento se dividió en dos pruebas.

Para la prueba uno se utilizaron 20 charolas de plástico de $0.33 \mathrm{~m}$ de ancho $\times 0.54 \mathrm{~m}$ de largo $\left(0.18 \mathrm{~m}^{2}\right)$, con $5 \mathrm{~cm}$ de profundidad, y cada una se tomó como unidad experimental. A cada charola se le hicieron 12 perforaciones a la misma distancia, y se colocó una capa de $4 \mathrm{~cm}$ de suelo con textura franco arenosa y pH de 6, obtenido del Rancho Experimental La Campana ubicado en $29^{\circ} 16^{\prime} 01^{\prime \prime} \mathrm{N}$ y $106^{\circ} 21^{\prime} 16^{\prime \prime} \mathrm{O}$. Se realizaron riegos durante 30 días antes de la siembra para eliminar del suelo semillas ajenas al experimento y evitar la emergencia de otras especies. La siembra se inició el 8 de agosto del 2013 y la distribución de la semilla se hizo al voleo. Se aplicaron $5 \mathrm{~kg}$ de semilla pura viable por hectárea ( $\mathrm{kg} \mathrm{SPV} \mathrm{ha-1)}$ para cada variedad (Cuadro 1)(11). La semilla se sembró a una profundidad de $0.5 \mathrm{~cm}$. Las charolas se distribuyeron en bloques al azar con cuatro repeticiones por variedad para evitar efecto de exposición. Se aplicó un riego inicial de $1.5 \mathrm{~L}$ de agua por charola y los riegos fueron similares para cada unidad experimental $(1.0$ y $0.5 \mathrm{~L})$ espaciados entre uno y cuatro días, manteniendo siempre la humedad del suelo a capacidad de campo. Las temperaturas dentro del invernadero fluctuaron entre 14 y $41{ }^{\circ} \mathrm{C}$. Las variables evaluadas fueron: emergencia (\% EM), densidad de plantas (DPL), altura de planta (APL), materia seca del primer corte (MS1), altura de rebrote (ARE), materia seca de rebrote (MS2) y
The study was conducted in a greenhouse located at the Facultad de Zootecnia y Ecología, Universidad Autónoma de Chihuahua during the summer in 2013. Five commercial varieties of sideoats grama grass were used: Niner $(\mathrm{Ni})$, Vaughn (Va) El Reno (Re), Kansas native-6107 (K-07) and Kansas native-6113 (K-13). The experiment was divided into two tests.

For test one, 20 plastic trays $0.33 \mathrm{~m}$ wide $\mathrm{x}$ $0.54 \mathrm{~m}$ long $\left(0.18 \mathrm{~m}^{2}\right)$ and $5 \mathrm{~cm}$ deep were used; each tray was an experimental unit. In each tray 12 perforations were made at the same distance, and covered with a layer of 4 $\mathrm{cm}$ of soil with sandy loam and $\mathrm{pH} 6$, obtained from Rancho Experimental La Campana located at $29^{\circ} 16^{\prime} 01^{\prime \prime} \mathrm{N}$ and $106^{\circ} 21^{\prime} 16^{\prime \prime} \mathrm{W}$. Watering was conducted for $30 \mathrm{~d}$ before planting in order to remove seeds from the soil and avoid the emergence of other species. Planting began on August 8, 2013 and the distribution of seed was random. Five kilograms of pure viable seed were applied per hectare ( $\mathrm{kg} \mathrm{SPV} \mathrm{ha-1)}$ for each variety (Table 1$)(11)$. The seed was sown at a depth of $0.5 \mathrm{~cm}$. The trays were distributed in randomized blocks with four replicates per variety to avoid exposure effect. An initial irrigation of $1.5 \mathrm{~L}$ of water per tray was applied, and the irrigation were similar for each experimental unit ( 1.0 and $0.5 \mathrm{~L}$ ) spaced between one and four days; later, soil was

Cuadro 1. Cantidad de semilla comercial sembrada por unidad experimental (parcela) de cinco variedades de pasto banderita

Table 1. Number of commercial seed sown by experimental unit (plot) of five varieties of sideoats grama grass

\begin{tabular}{lcc}
\hline Variety & \% SPV & Adjusted density planting (g) \\
\hline Niner & 75 & 0.120 \\
Vaughn & 76 & 0.117 \\
El Reno & 75 & 0.120 \\
Kansas-6107 & 79 & 0.112 \\
Kansas-6113 & 54 & 0.165 \\
\hline
\end{tabular}

$\% \mathrm{SPV}=$ percentage of pure viable seed. 
supervivencia (\% SV). La medición de DPL comenzó tres días después de la siembra y se llevaron conteos diarios durante un mes. Para DPL se tomó en cuenta el último conteo antes del primer corte, para APL se midieron tres plantas al azar por cada unidad experimental, y en la misma fecha se realizó el primer corte para obtener MS1. Estas tres variables se evaluaron 60 días después de la siembra. La biomasa se secó durante cinco días en invernadero, posteriormente se sometieron a temperatura constante de $65^{\circ} \mathrm{C}$ durante $24 \mathrm{~h}$ en un horno de secado marca Felisa para lograr un peso constante, se pesó en una báscula analítica marca Sartorius. Se continuó con los riegos y se dejó crecer el rebrote por 21 días para efectuar el segundo corte; en esta fecha se midieron ARE y MS2. El secado y pesado se realizó con la misma técnica del primer corte. Para estimar \% SV se tomó en cuenta la mayor densidad registrada y el número de plantas vivas rebrotadas.

En la prueba dos se utilizaron 25 macetas cilíndricas elaboradas con bolsas negras de plástico de $30 \mathrm{~cm}$ de profundidad por $10 \mathrm{~cm}$ de diámetro. Las bolsas se llenaron a $25 \mathrm{~cm}$ con el mismo suelo utilizado en las charolas. Se sembraron 20 semillas de cada variedad por maceta a $0.5 \mathrm{~cm}$ de profundidad. De las plantas emergidas se dejaron tres plántulas por maceta de aproximadamente $3 \mathrm{~cm}$ de altura para ser evaluadas. Las macetas se colocaron sobre una mesa del invernadero, distribuidas en bloques al azar con cuatro repeticiones. Se aplicaron riegos diarios y uniformes para mantener humedad del suelo a capacidad de campo. Las plantas se sacaron de las macetas y se separaron del suelo 35 días posteriores a la siembra. Se separó la biomasa aérea de la radícula, la cual se secó y pesó utilizando la misma metodología de la prueba uno. Las variables evaluadas fueron: longitud de raíz (LR), altura de biomasa aérea (ABA) y proporción raíz-biomasa aérea (PR-BA).

Se realizó un análisis por componentes principales (ACP) y análisis por conglomerados maintained at field capacity. Temperatures inside the greenhouse fluctuated between 14 and 41 ${ }^{\circ} \mathrm{C}$. The variables evaluated were: emergence $(\mathrm{EM} \%)$, plant density (PD), plant height $(\mathrm{PH})$, dry matter of the first cut (DM1), height of regrowth (HR), dry matter regrowth (DM2), and survival (SV\%). Measurements of PD started three days after seeding and daily counts were taken during a month. To PD it took into account the last count before the first cut. For PH three plants were measured at random for each experimental unit and at the same time the first cut was made for DM1. These three variables were evaluated at $60 \mathrm{~d}$ after planting. Biomass was dried at constant temperature, of $65^{\circ} \mathrm{C}$ for $24 \mathrm{~h}$ in an oven (Felisa brand) to constant weight. Later samples were weighed on an analytical scale (Sartorius brand). Work continued on the irrigation and grown regrowth for $21 \mathrm{~d}$ to make the second cut; on this date HR and DM2 were measured. The drying and weighing was carried out with the same technique as the first cut. Estimate of SV\% took into account the highest recorded density and the number of live plants that regrew.

For test two, in order to evaluate plant growth and development sideoats grama seed were planted in cylindrical pots. Each pot was $30 \mathrm{~cm}$ deep by $10 \mathrm{~cm}$ in diameter. The bags were filled to $25 \mathrm{~cm}$ with the same soil used in the trays. A total of 20 seeds per variety were seeded $0.5 \mathrm{~cm}$ deep at each pot. Three seedlings were allowed to growth per pot for further evaluation. The pots were placed on a table in the greenhouse, distributed in randomized blocks with four replications. The soil into the pots was maintained at field capacity. The plants were removed from the pots and left in the ground for $35 \mathrm{~d}$ after sowing. The above ground biomass of the radicle was separated, dried and weighed using the same methodology. The variables evaluated were: root length ( $R L)$, height, above ground biomass $(\mathrm{aDM})$ and ratio root-biomass $\mathrm{r}(\mathrm{R}-\mathrm{aDM})$.

Principal component analysis (PCA) and cluster analysis (CA) by Ward linkage method for 
(AC) mediante el método de ligamiento de Ward para la agrupación de variedades(12). Las variedades se compararon entre sí a través de análisis multivariado (MANOVA) y contrastes ortogonales, bajo los estadísticos de Wilks' Lambda, Pillai's Trace, Hotelling-Lawley Trace y Roy's Greatest Root. El programa estadístico utilizado fue SAS(12). Las gráficas de dispersión y dendograma se obtuvieron a través de MINITAB.

El Cuadro 2 muestra una amplia diversidad en las variables evaluadas de las cinco variedades de pasto banderita, principalmente en \% EM y DPL, sin embargo, en ARE y PR-BA se observó menor variación morfológica. Lo anterior muestra el potencial de establecimiento que existe en estas variedades. El ACP mostró que los dos primeros componentes explican el $76.9 \%$ de la variación (Cuadro 3). El CP1 presenta un equilibrio en casi todas las variables evaluadas (Cuadro 4), con excepción de \% EM y \% SV. Este componente se caracteriza por agrupar variables relacionadas con producción de forraje y refleja rasgos relacionados con la capacidad de crecimiento. En el CP 2 las variables con mayor contribución fueron \% SV, DPL y PRBA (Cuadro 3). Las diferencias que grouping varieties(12) was performed. The varieties were compared with each other through multivariate analysis (MANOVA) and statistics of orthogonal contrasts under the Wilks' Lambda, Pillai's Trace, Hotelling-Lawley Trace and Roy's Greatest Root. The statistical program

Cuadro 2. Valores máximos y mínimos de 10 variables evaluadas en cinco variedades comerciales de pasto banderita

Table 2. Maximum and minimum values of 10 variables evaluated in five commercial varieties of sideoats grama grass

\begin{tabular}{lc}
\hline Variable & $\begin{array}{c}\text { Interval } \\
\text { minimum-maximum }\end{array}$ \\
\hline Emergence, \% & $0.25-57.0$ \\
Plant density, P m-2 & $78.0-244.0$ \\
Plant height, cm & $2.2-13.3$ \\
Dry matter, g & $5.0-5.7$ \\
Survival, \% & $32.0-71.0$ \\
Regrowth height, cm & $1.2-4.5$ \\
Regrowth dry matter, g & $2.1-31.6$ \\
Root length, cm & $25.0-40.0$ \\
Above ground height, cm & $7.5-27.5$ \\
Root-biomass ratio, 1-2 & $1.5-3.8$ \\
\hline
\end{tabular}

Cuadro 3. Valores característicos y proporción de la varianza total, basados en 10 variables de cinco variedades comerciales de pasto banderita

Table 3. Characteristic values and proportion of the total variance, based on 10 variables in five commercial varieties of sideoats grama grass

\begin{tabular}{cccc}
\hline $\begin{array}{c}\text { Principal } \\
\text { component }\end{array}$ & $\begin{array}{c}\text { Characteristic } \\
\text { value }\end{array}$ & $\begin{array}{c}\text { Proportion of overall } \\
\text { variance explained (\%) }\end{array}$ & $\begin{array}{c}\text { Proportion of } \\
\text { cumulative variance (\%) }\end{array}$ \\
\hline 1 & 6.33 & 63.31 & 63.31 \\
2 & 1.36 & 13.68 & 76.99 \\
3 & 1.02 & 10.22 & 87.21 \\
4 & 0.48 & 4.79 & 92.0 \\
5 & 0.38 & 3.88 & 95.88 \\
6 & 0.18 & 1.82 & 97.71 \\
7 & 0.13 & 1.28 & 98.99 \\
8 & 0.05 & 0.5 & 99.48 \\
9 & 0.03 & 0.3 & 99.77 \\
10 & 0.02 & 0.2 & 100 \\
\hline
\end{tabular}


presentan estas variedades, pudieran estar relacionadas con capacidad o facilidad de supervivencia durante la etapa crítica de establecimiento, ya que son originarias de diferentes ambientes agroecológicos(13-17).

Al obtener el coeficiente de determinación $\left(R^{2}\right)$ para cada una de las variables originales, respecto a los dos primeros $\mathrm{CP}$, se presentaron correlaciones significativas en las diversas variedades, y con respecto al $C P 1$ se presentaron diferencias significativas $(P<0.05)$ en la mayoría de las variables evaluadas (Cuadro 4). Se observa que el coeficiente de determinación en la correlación del CP 1 con las variables originales, demostró que solo las variables \% EM y \% SV no tuvieron contribución significativa.

El CP 2 presentó una correlación significativa $(r=85.1 \% ; P<0.0 .0001)$ con \% SV. La dispersión que muestra la Figura 1, refleja diversidad morfológica existente en estas variedades, donde las variables que más contribuyeron fueron \% SV, PR-BA, ABA y DPL. La variación morfológica que presentan las used was SAS(12). The scatter plots and dendrogram were obtained through MINITAB.

Table 2 shows a wide variation in the variables evaluated in the five varieties of sideoats grama grass. The higest variation was on \% MS and PD; lowest variation was obtained for $\mathrm{HR}$ and $r(R-a D M)$. The high variability represent potential for selection the most appropriated varieties in order to ensure establishment. The PCA showed that the first two components explain $76.9 \%$ of the variance (Table 3 ). The PC1 presents a balance in almost all variables evaluated (Table 4), except EM\% and SV\%. This component is characterized by grouping variables related to forage production and related capacity reflects growth traits. In PC2 variables that contributed most were SV\%, PD and PRBA (Table 3). The differences in these varieties could be related to ability for survival during the critical stage of establishment, as they originate from different agro-ecological environments(13-17).

To obtain the coefficient of determination $\left(R^{2}\right)$ for each of the original variables, with respect to the first two PC, significant correlations were

Cuadro 4. Vectores característicos y coeficientes de determinación $\left(R^{2}\right)$ de las variables de mayor valor descriptivo, respecto a su componente principal en variedades de pasto banderita

Table 4. Characteristic vectors and coefficients of determination $\left(R^{2}\right)$ variables of more descriptive value relative to its principal component in varieties of sideoats grama grass

\begin{tabular}{lcccc}
\hline \multirow{2}{*}{ Variable } & \multicolumn{2}{c}{ Characteristic vector } & & \multicolumn{2}{c}{ Coefficient of determination $\left(\mathrm{R}^{2}\right)$} \\
\cline { 2 - 4 } & $\mathrm{CP} 1$ & $\mathrm{CP} 2$ & & \\
\hline Emergence, \% & 0.13 & 0.26 & $0.339 \mathrm{~ns}$ & $0.302 \mathrm{~ns}$ \\
Plant density, P m-2 & 0.30 & 0.44 & $0.764^{* *}$ & $0.514^{*}$ \\
Plant height, cm & 0.38 & 0.03 & $0.957^{* *}$ & $0.037 \mathrm{~ns}$ \\
Dry matter, g & 0.38 & 0.06 & $0.954^{* *}$ & $0.065 \mathrm{~ns}$ \\
Survival, \% & 0.08 & 0.73 & $0.195 \mathrm{~ns}$ & $0.851^{* *}$ \\
Root length, cm & 0.35 & -0.03 & $0.880^{* *}$ & $-0.036 \mathrm{~ns}$ \\
Regrowth of dry matter, g & 0.37 & -0.02 & $0.943^{* *}$ & $-0.019 \mathrm{~ns}$ \\
Root length, cm & 0.31 & -0.12 & $0.782^{* *}$ & $-0.138 \mathrm{~ns}$ \\
Biomass height, cm & 0.36 & -0.23 & $0.897^{* *}$ & $-0.271 \mathrm{~ns}$ \\
Root-biomass ratio 1:2 & -0.33 & 0.37 & $-0.826^{* *}$ & $0.431^{*}$ \\
\hline
\end{tabular}

$(P<0.05) ; * *(P<0.01)$.

$\mathrm{ns}=$ no significant. 
variedades de banderita, puede predecir que de acuerdo a la capacidad de adaptación a diferentes temperaturas, precipitaciones y tipos de suelo, es posible establecer grupos con características de interés, más que por localidades o entidades de origen $(18,19,20)$.

El análisis de conglomerados jerárquicos, basados en el método de ligamiento WARD, presentó tres grupos. El grupo uno (G-I) integró a las variedades Niner y Vaughn, originarias de Socorro, Nuevo México, EE.UU y Vaughn, Nuevo México, EE.UU, respectivamente. En general, estas variedades se caracterizaron por presentar los valores más altos de las variables evaluadas. De las dos variedades, la Niner presentó los presented in different varieties, and with respect to PC one significant difference $(P<0.05)$ were presented at the most of the evaluated variables (Table 4). It is noted that the coefficient of determination in correlation PC1 with the original variables, showed that only the variables $\mathrm{EM} \%$ and SV \% had no significant contribution. The PC2 was significantly correlated $(r=85.1 \%$; $\mathrm{P}<0.0 .0001$ ) with SV \%.

The dispersion shown in Figure 1 reflects existing morphological diversity in these varieties; variables that contributed most were $\mathrm{SV} \%, \mathrm{r}(\mathrm{R}-\mathrm{aDM}), \mathrm{aDM}$ and PD. Morphological variation of sideoats grama grass can predict varieties more able according to the ability to

Figura 1. Distribución de la diversidad de cinco variedades de pasto banderita en función de los dos primeros componentes principales, obtenidos con matriz de correlación de 10 variables

Figure 1. Distribution of the diversity of five varieties of sideoats grama grass based on the first two principal components obtained with the correlation matrix of 10 variables
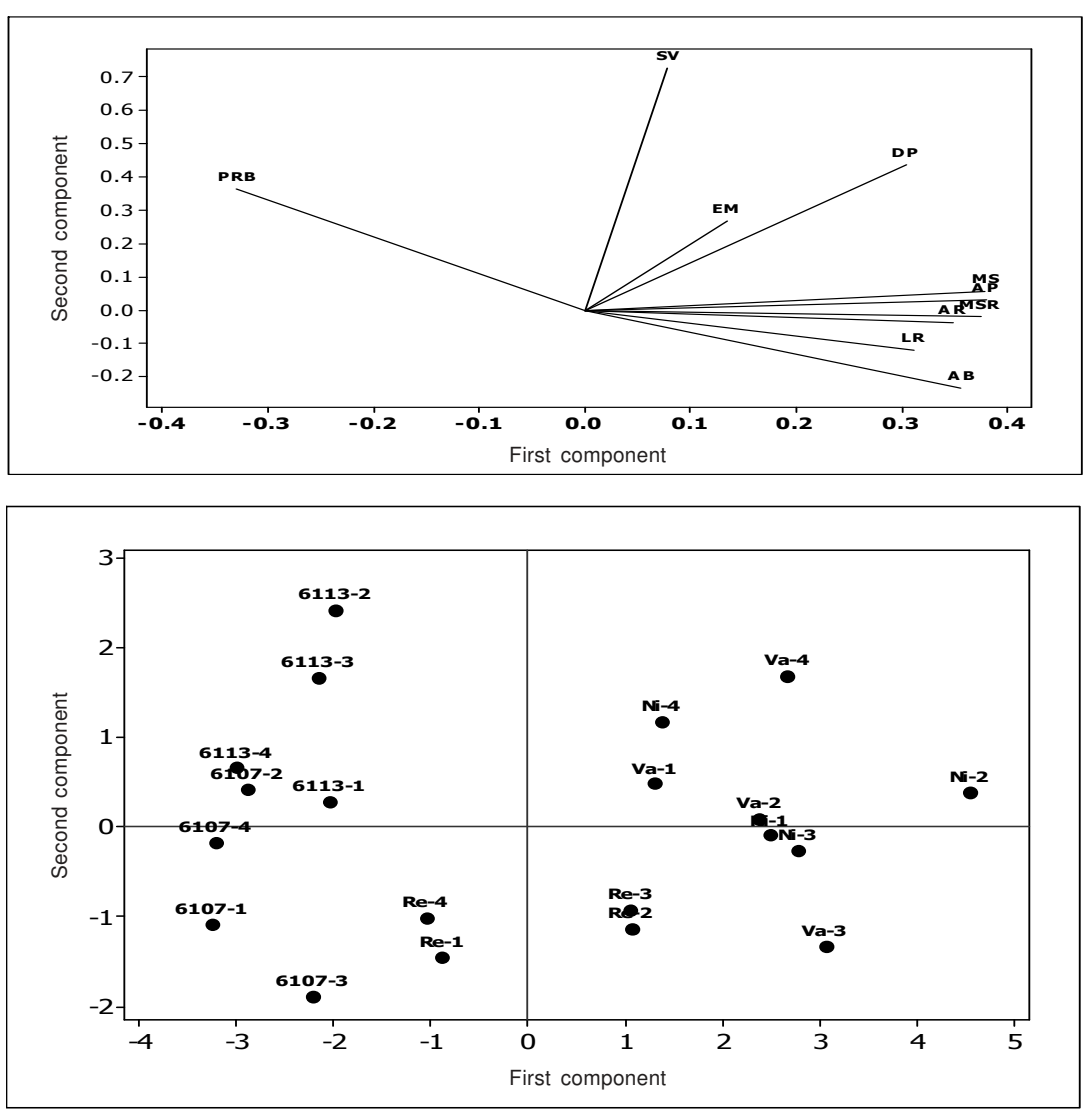
valores más altos en $\mathrm{DPL}, \mathrm{MS1}, \mathrm{ARE}$, $\mathrm{LR}$ y $\mathrm{ABA}$; sin embargo, la variedad Vaughn solo presentó los mayores valores en APL y MS2. El grupo dos (G-II) reunió solo a una variedad (El Reno), originaria de El Reno, Oklahoma, EE.UU. Esta variedad se caracterizó por presentar valores intermedios en las variables evaluadas; sin embargo, otros autores mencionan que se comporta mejor en ambientes con bajas temperaturas(21). El grupo tres (G-III) integró a las variedades $\mathrm{K}-07$ y K-13, originarias de Kansas, EE.UU. Estas variedades se caracterizaron por presentar los valores más bajos de las variables evaluadas. La variedad $\mathrm{K}-07$ mostró los valores más bajos en \% EM, DPL, APL, MS1, \% SV y MS2. La variedad K-13 mostró los valores más bajos en ARE, LR y ABA (Figura 2). Un aspecto importante es que la variación morfológica observada, probablemente es el resultado de la selección y mejoramiento a que fueron sometidas. Con respecto a estos resultados, diferentes autores reportan variaciones morfológicas en esta especie $(22,23,24)$. adapt to different temperatures, rainfall and soil types, is possible to establish groups with characteristics of interest, rather than locations or source features $(18,19,20)$.

The cluster analysis was based on the method of WARD linkage consisting of three groups. Group one (G-I) was composed of the Niner and Vaughn varieties originating from Socorro, New Mexico, USA and Vaughn, New Mexico, USA, respectively. In general, these varieties were characterized as having the highest values in the variables evaluated. For the two varieties, Niner had the highest values of PD, DM1, HR, $A B D M$, and RL; however, only the variety Vaughn had the highest values in PH and DM2. Group two (G-II) only consisted of one variety (EI Reno), originally from El Reno, Oklahoma, USA This variety was characterized with intermediate values. However, other authors mention good performance at environments with low temperatures(21). Group Three (G-III) integrated varieties $\mathrm{K}-07$ and $\mathrm{K}-13$, originating from Kansas,

Figura 2. Dendograma del análisis de 10 variables para cinco variedades de pasto banderita con base en el método de ligamiento Ward

Figure 2. Dendrogram analysis of 10 variables for five varieties of sideoats grama grass based on the method of Ward linkage

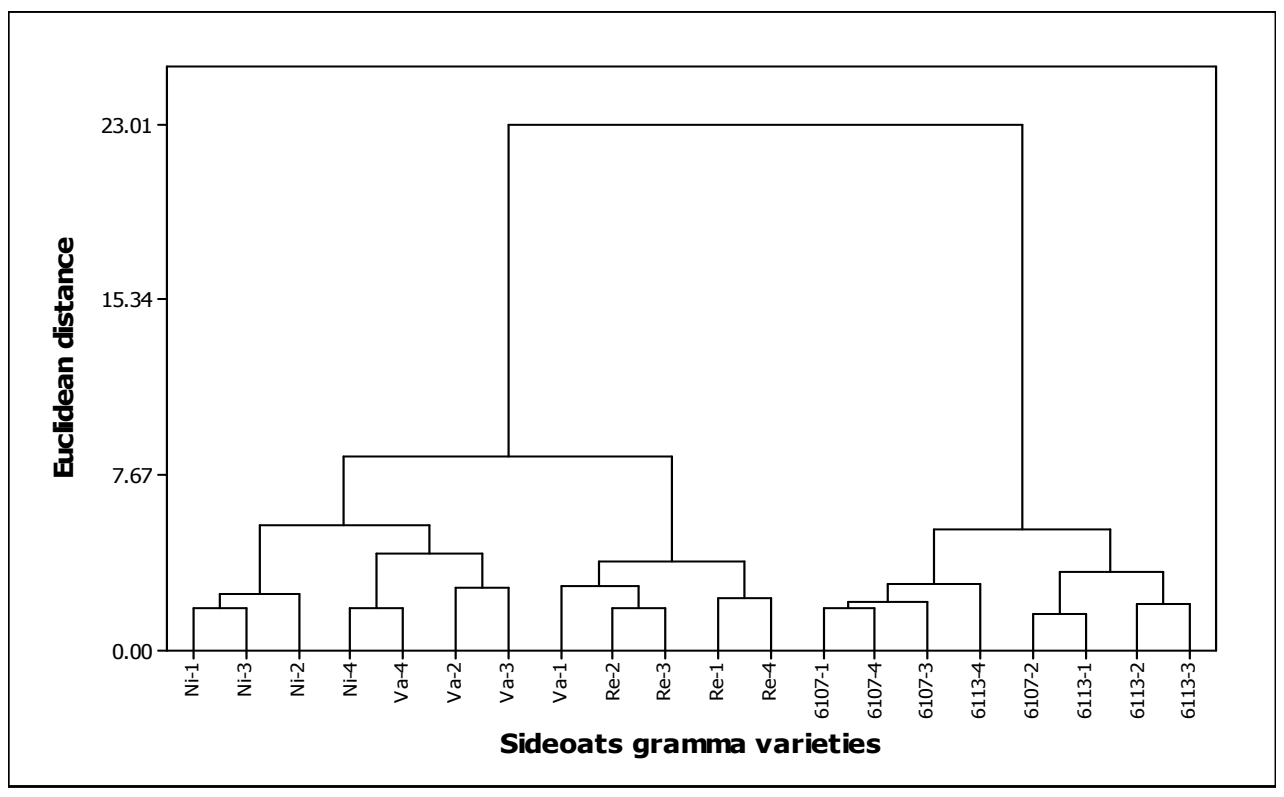


Al contrastar las variables con el análisis multivariado (MANOVA), se pudieron clasificar las variedades por su importancia productiva a los dos meses de establecimiento de la siguiente manera: Niner y Vaughn, no presentaron diferencias entre ellas, pero éstas fueron superiores $(P<0.05)$ a El Reno, K-07 y K-13. Así mismo, El Reno fue superior $(P<0.05)$ a K-07 y K-13. El Cuadro 5 muestra los valores de los estadísticos; Wilks' Lambda, Pillai's Trace, Hotelling-Lawley Trace y Roy's Greatest Root. Por los resultados anteriores es importante considerar que la capacidad productiva de una planta, está relacionada con la calidad de semilla, además del potencial genético que tiene cada variedad(17). Sin embargo, las condiciones climáticas y ubicación, dependen en gran medida de la respuesta productiva, ya sea por especie o variedad de pasto(25,26). Trabajos anteriores reportan a los cultivares Niner y Vaughn con un destacado desempeño productivo en los estados de Colorado y Nuevo México en ambientes con 200 y 400 mm de precipitación(27). Además se reporta que la variedad El Reno fue inferior en algunos parámetros productivos, al compararla con ecotipos de banderita recolectados en Durango y Zacatecas(10). Con respecto a las
USA. These varieties were characterized by having the lowest values. The $\mathrm{K}-07$ variety showed the lowest values in \% $\mathrm{EM}, \mathrm{PD}, \mathrm{PH}$, DM1, DM2 and SV\%. The K-13 variety showed the lowest values in $\mathrm{HR}, \mathrm{RL}$ and ABDM (Figure 2). An important aspect is that the morphological variation observed is probably the result of selection and breeding performed on those varieties. With regard to these results, different authors report morphological variations within this species $(22,23,24)$.

By comparing the variables with multivariate analysis (MANOVA), the varieties can be classified for its productive importance at $2 \mathrm{mo}$ of establishment as follows: Niner and Vaughn, no differences between them, but they were higher $(P<0.05)$ than $\mathrm{El}$ Reno, $\mathrm{K}-07$ and $\mathrm{K}-13$. Likewise, El Reno was higher $(P<0.05)$ than $\mathrm{K}-07$ and $\mathrm{K}-13$. Table 5 shows the values of the statistics; Wilks' Lambda, Pillai's Trace, HotellingLawley Trace and Roy's Greatest Root. From the above results, it is important to consider that the productive capacity of a plant, is related to the quality of seed, as well as the genetic potential of each variety(17). However, location

Cuadro 5. Comparación de cinco variedades de banderita, con MANOVA y los valores de probabilidad de cuatro estadísticos

Table 5. Comparison of five varieties of sideoats grama grass with MANOVA and the probability values from four statistical tests

\begin{tabular}{|c|c|c|c|c|}
\hline \multirow[b]{2}{*}{ Variety comparison } & \multicolumn{3}{|c|}{ Statistics } & \multirow[b]{2}{*}{ Roy's Greatest Root } \\
\hline & Wilks' Lambda & Pillai's Trace & Hotelling-Lawley Trace & \\
\hline $\mathrm{Ni}$ vs Va & $P>0.05$ & $P>0.05$ & $P>0.05$ & $P>0.05$ \\
\hline $\mathrm{Ni}$ vs $\mathrm{Re}$ & $P \leq 0.0034$ & $P \leq 0.0034$ & $P \leq 0.0034$ & $P \leq 0.0034$ \\
\hline Ni vs 6107 & $P \leq 0.001$ & $P \leq 0.001$ & $P \leq 0.001$ & $P \leq 0.001$ \\
\hline Ni vs 6113 & $P \leq 0.0015$ & $P \leq 0.0015$ & $P \leq 0.0015$ & $P \leq 0.0015$ \\
\hline Va vs $\operatorname{Re}$ & $P \leq 0.0125$ & $P \leq 0.0125$ & $P \leq 0.0125$ & $P \leq 0.0125$ \\
\hline Va vs 6107 & $P<0.001$ & $P<0.001$ & $P<0.001$ & $P<0.001$ \\
\hline Va vs 6113 & $P \leq 0.0012$ & $P \leq 0.0012$ & $P \leq 0.0012$ & $P \leq 0.0012$ \\
\hline Re vs 6107 & $P \leq 0.0104$ & $P \leq 0.0104$ & $P \leq 0.0104$ & $P \leq 0.0104$ \\
\hline Re vs 6113 & $P \leq 0.0108$ & $P \leq 0.0108$ & $P \leq 0.0108$ & $P \leq 0.0108$ \\
\hline 6107 vs 6113 & $P>0.05$ & $P>0.05$ & $P>0.05$ & $P>0.05$ \\
\hline
\end{tabular}

$\mathrm{Ni}=$ Niner, Va= Vaughn, $\mathrm{Re}=\mathrm{El}$ Reno, 6107= Kansas nativa-6107, 6113= Kansas nativa-6113. 
variedades Kansas nativas sólo se encontró que fueron utilizadas en 2012 en programas de resiembra en el estado de Chihuahua y presentaron índices bajos en establecimiento y producción.

Se identificaron a las variedades Niner y Vaughn con características morfológicas que reflejan alto potencial forrajero. La variedad El Reno presentó un potencial intermedio para producción de forraje, de acuerdo a las variables consideradas. Las variedades Kansas nativa-6107 y Kansas nativa-6113, presentaron el menor potencial para producción de forraje bajo invernadero. El estudio de los atributos de mayor importancia productiva y variación morfológica de las variedades de pasto banderita, dará la oportunidad de incorporarlas a programas de resiembra con resultados a menor plazo. Se recomienda la evaluación en condiciones de campo para poder sugerir con mayor certeza la inclusión de las variedades Niner y Vaughn en programas de resiembra y rehabilitación de agostaderos en el estado de Chihuahua.

\section{AGRADECIMIENTOS}

Al Consejo Nacional de Ciencia y Tecnología (CONACYT), a la Universidad Autónoma de Chihuahua (UACH) y al Instituto Nacional de Investigaciones Forestales Agrícolas y Pecuarias (INIFAP).

\section{LITERATURA CITADA}

1. Pellant $M$, Shaver $P$, Pyke DA, Herrick JE. Interpreting Indicators of rangeland health. USDI, Bureau of Land Management. Tech. Ref. 1734-6. Versión 3. Denver, CO. USA; 2005.

2. Jurado $P$, Domínguez $H$, Melgoza A, Morales CR. Emergencia y crecimiento del zacate banderilla [Bouteloua curtipendula (Michx.) Torr.] con biosólidos en condiciones de sequía. Tecnociencia Chihuahua 2011;6:57-67.

3. Gay ChW, Dwyer DD, Steger RE. New Mexico range plants. New Mexico State University. Coop Ext Serv Cir 1970;374:245. and weather conditions depend largely on the productive response, of either species or variety of grass $(25,26)$. Previous work has reported that Niner and Vaughn cultivars with outstanding production performance in the states of Colorado and New Mexico in environments with 200 to $400 \mathrm{~mm}$ of precipitation(27). Also, it has been reported that the variety El Reno was lower in some productive parameters compared to sideoats grama grass ecotypes collected in Durango and Zacatecas(10). Regarding Kansas native varieties it was only found that they were used in 2012 in reseeding programs in the state of Chihuahua, but low rates of establishment and production were obtained.

The Niner and Vaughn varieties were identified with morphological features reflecting high forage potential. The El Reno variety presented an intermediate potential for forage production, according to the variables considered. The Kansas native-6107 and Kansas native-6113, are the varieties that had the lowest potential for forage production in greenhouses. The study of attributes of sideoats grama grass varieties that are of a more productive and morphological variation importance shows which varieties to incorporate in replanting programs in order to achieve results in a shorter time. The evaluation herein under field conditions shows with greater certainty a recommended inclusion of varieties Niner and Vaughn for reseeding programs on rangelands state of Chihuahua.

\section{ACKNOWLEDGMENTS}

The National Council of Science and Technology (CONACYT), the Autonomous University of Chihuahua (UACH) and the National Institute of Livestock Agricultural and Forestry Research (INIFAP).

End of english version 


\section{CARACTERIZACIÓN DE VARIEDADES DE PASTO BANDERITA PARA REHABILITACIÓN DE PASTIZALES}

4. Willard EE, Schuster JL. An evaluation of an interseeded sideoats grama stand four years after establishment. J Range Management 1971;24:223-226.

5. Beltrán LS, García DCA, Hernández AJA, Loredo OC, Urrutia MJ, González ELA, Gámez VHG. "Banderilla Diana" Bouteloua curtipendula (Micch.) Torr. Nueva variedad de pasto para zonas áridas y semiáridas. Rev Mex Cienc Pecu 2013;4(2):217-221.

6. Sedivec KK, Tober DA, Duckwitz WL, Hendrickson JR. Grass varieties for North Dakota. North Dakota State University. Fargo, North Dakota USA. 2001.

7. Royo MH, Sierra JS, Morales CR, Jurado P. Prácticas de conservación y rehabilitación de agostaderos. S.E. La Campana-Madera. INIFAP-SAGARPA: Folleto Técnico Nº 29. 2010.

8. Beltrán LS, Loredo C. ¿Cuándo, dónde y cómo realizar una resiembra de pastos? C.E. San Luis. INIFAP-SAGARPA. Desplegable técnico. № 2. 2005.

9. SNICS. Servicio Nacional de Inspección y Certificación de Semillas 2003. Disponible: http://www.snics.sagarpa.gob.mx. 2003.

10. Sánchez FF, Hernández JF, Carrete F, Plascencia R, Quero A. Comportamiento del rendimiento de semillas de 12 genotipos y una variedad de pasto banderita. Reunión Internacional de Manejo de Pastizales y Producción Animal 2012;374-378.

11. Morales NCR, Royo MH, Lara CR. Guía técnica para la producción y cosecha de la semilla de pastos nativos en Chihuahua. S.E. La Campana-Madera. INIFAP-SAGARPA. Folleto Técnico N 29. 2010.

12. SAS. SAS/STAT User's Guide (versión9.1.3). Cary, NC, USA: SAS Inst. Inc. 2006

13. Nisar MF, Mumtaz AS, Ashraf M, Majeed A, Hussain K, Nawas K. Evaluating the agro-morphological variation in Panicum antidotale in Cholistan Desert, Pakistan. Int J Agr Biol 2010;12:416-420.

14. Ferdinandez YSN, BE Coulman. Genetic relationships among smooth bromegrass cultivars of different ecotypes detected by AFLP markers. Crop Sci 2004;44:241-247.

15. Casler MD. Ecotypic variation among switchgrass populations from the Northern USA. Crop Sci 2005;45:388-398.

16. Damalas CA, Dhima VK, Eleftherohorinos GI. Morphological and physiological variation among species of the genus
Echinochloa in Northern Greece. Weed Sci 2008;56:416423.

17. Morales NCR, Quero AR, Melgoza A, Martínez M, Jurado P. Diversidad forrajera del pasto banderita [Bouteloua curtipendula (Michx.) Torr.] en poblaciones de zonas áridas y semiáridas de México. Téc Pecu Méx 2009;47:231-244

18. Aguado-Santacruz GA, Rascón Q, Pons JL, Grageda O, García-Moya E. Manejo biotecnológico de gramíneas forrajeras. Tec Pecu Méx 2004;42:261-276.

19. Avendaño $\mathrm{CH}$, Ramírez $\mathrm{P}$, Castillo $\mathrm{F}$, Chávez JL, Rincón $\mathrm{G}$. Diversidad isoenzimática en poblaciones nativas de frijol negro. Rev Fitotec Mex 2004;27:31-40.

20. Núñez-Colín CA. Distribución y caracterización eco-climática del membrillo cimarrón (Amelanchi erdenticulata (Kunth) Koch) en México. Rev Chapingo, Ser Hortic 2010;16:195206.

21. Lloyd-Reilley J, Smith F. Plant guide for South Texas germplasm sideoats grama. USDA-Natural Resources Conservation Service. http://www.nrcs.usda.gov/. Accessed Apr 7, 2014.

22. Rubio AFA. Caracterización inicial de 59 ecotipos de zacate banderilla Bouteloua curtipendula (Michx.) Torr., en Calera, Zacatecas. Manejo de Pastizales 1989;3:3-9.

23. Verdal JD, Mayland HF, Asay KH, Jefferson PG. Variation in agronomic and morphological traits among Russian wildrye accessions. Crop Sci 1999;39:1890-1895.

24. Villar RF, Arenas $F$, Lambers $H$, Panadero $P$, Maranon $T$, Quero JL. Variation in relative growth rate of 20 Aegilops species (Poaceae) in the field: the importance of net assimilation rat or specific leaf area depends on the time scale. Plant Soil 2005;272:11-27.

25. Seymour R, Seymour J, Blackford C. Six basic elements for a successful native grass and forb establishment. 3rd ed. Kentucky, USA: Round Stone Native Seed, LLC. 2008.

26. Dwight $T$, Jensen N, Duckwitz W, Knudson M. Sideoats grama (Bouteloua curtipendula) performance trials North Dakota, South Dakota, and Minnesota. USDA, Natural Resources Conservation Service, Bismarck, North Dakota. USA. 2010.

27. Veneciano JH. Gramíneas estivales perennes para ambientes semiáridos: Características y productividad. Sitio Argentino de Producción Animal. Estación Experimental Agropecuaria San Luis. Información Técnica 2006;171:1-84. 
